
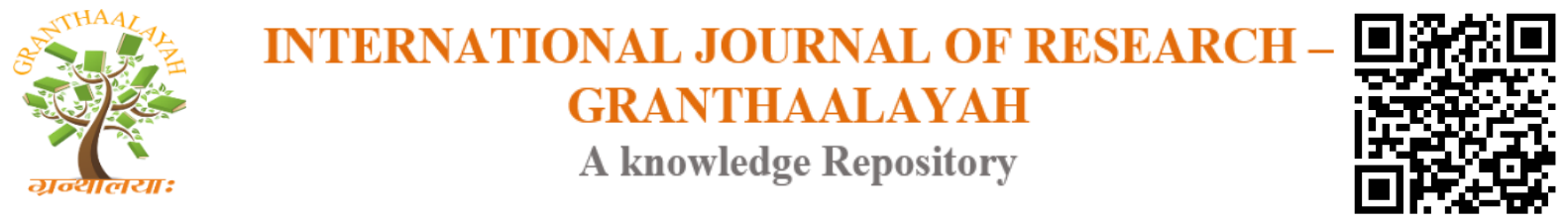

Management

\title{
SIGNIFICANT RELATIONSHIP INTELLECTUAL CAPITAL AND MACRO ECONOMICS: A CASE STUDY
}

\author{
Ahmad Subagyo ${ }^{1}$, Siti Zulaikha Wulandari ${ }^{2}$, Desmadi Saharuddin ${ }^{3}$ \\ ${ }^{1}$ STIE GICI Business School Depok - Indonesia \\ ${ }^{2}$ Fakultas ekonimi dan Bisnis Unsoed - Indonesia \\ ${ }^{3}$ Lecturer of Universitas Islam Negeri Syarif Hidayatullah Jakarta - Indonesia
}

\begin{abstract}
This paper aims to investigate the relationship between intellectual capital of several companies in Indonesia and macroeconomic variables Indonesia during the period 2011-2017 at 61 companies listed on the Stock Exchange. In this study using several intellectual capital variables in 61 companies and some Indonesian macro-economic variables are intellectual capital variable, Indonesian bank interest rate, consumer price index, producer price index, exchange rate index, inflation. This paper uses multiple regression data analysis techniques with OLS proposal model, linear difference and log analysis. From the results of studies that have been done can be explained that with the OLS regression model the relationship between several variable intellectual capital with some macroeconomic variables partially and simultaneously significant, as well as the difference. With log linear regression model analysis relationship between several variable intellectual capital with some macro economic variable simultaneously significant and partially between some variable intellectual capital significant and not significant partially with macro economic variable.
\end{abstract}

Keywords: Intellectual Capital; Macro Economy and Multiple Regression.

Cite This Article: Ahmad Subagyo, Siti Zulaikha Wulandari, and Desmadi Saharuddin. (2020). "SIGNIFICANT RELATIONSHIP INTELLECTUAL CAPITAL AND MACRO ECONOMICS: A CASE STUDY." International Journal of Research - Granthaalayah, 8(4), 112-118. https://doi.org/10.29121/granthaalayah.v8.i4.2020.67.

\section{Introduction}

\subsection{Background}

Some of the things underlying the occurrence of macroeconomic growth in a country and constraints and development are discussed more deeply in macroeconomics A2 scale. Many learners use the principle of human capital in explaining this. For an economy the use of human capital is made in the idea of measure quality assessing an available input, in producing goods and services. A lot of research is done using variable intellectual capital or human capital assessment 
in some countries such as England, Europe, USA and including in Indonesia is still very new. Intellectual capital or commonly called and in short with human capital is all knowledge, competence and skill embodied by each individual in making the creation of prosperity both personally, economically and socially. By capitalize the investment tools, skills and knowledge competencies that are owned, and lead to the accumulation of the creation of good human capital. With this informal investment, indirectly, human capital investments in other values will flow in the formal education or workplace channels through the company's training. As the intellectual capital increases, it can lead to several things: first there will be a positive spillover effect in terms of labor productivity per individual that will indirectly contribute to the improvement of economic growth. Secondly, with the intellectual captains and skilled labor, flexibility can ultimately make adjustments to technological changes and can change the pattern of demand to the level of structural work function. Thirdly, better human resources will increase welfare to higher levels because workers with high human resources will be paid and can contribute to economic value. Fourth, with strong intellectual capital will be able to make innovation and innovation promotion tool for economic growth on a long-term scale. In today's globalized world there is a tendency of developed countries to try to attract intellectual workers to want workers in their places. Finally, with many countries and companies having intellectual capital qualified and competent to remain active in the economy, it will be able to support the progress and reduce the poverty level in a country.

\section{Materials and Methods}

\subsection{Literature Review}

Assessment of human capital or intellectual capital at the macro level is an assessment of the skills, knowledge, and abilities of workers in the company to create value both in short and long term. According to that understanding, both workers and residents in a country are expected to work maximally, so that will be able to create what is intellectual capital / human capital. The existence of intellectual development of capital / human capital one of the things that need to be realized given the constantly changing economic and environmental conditions, so that the development of knowledge for sustainable human capital is indispensable in modern society today. Indirectly in the end the process of shrinking intellectual capital / human capital can not be ignored, so the need for permanent additional injection and renewal and acquire more recent knowledge. The process of increasing and developing human capital is also directly influenced by the level of technological development in the country. There is no empirical explanation which gives the conclusion that there is no dependence on the depreciation of human capital with the passage of time. The occurrence of depreciation or amortization of human capital / intellectual capital in the short term should be replaced with the emergence of new knowledge of human capital. Thus compensation from the intellectual value of capital is considered important not only at the company level but also at the economic level of a country as a whole.

In determining human capital or intellectual capital at the macro level, enabling the calculation of human capital by using a constituent valuation strategy. Guided by seeing the value of depreciation in human capital, so that in the end human capital will be reduced by applying the depreciation value in $\left[\begin{array}{ll}1 & \&\end{array} 2\right]$. Human capital assessment strategy at the macro level, can use real wage rate evaluation model that exist in each country. Depreciation value of human capital in case of 
recovery in terms of knowledge and ability to make the process of motivation in solving the problem solution. This proposal is the principle of the estimated value of human capital in twentyfive countries in the European Union excluding the State of Luxembourg and Greece. The decline in the value of human capital resulted in the reduction of human capital in aggregate. Some of the many factors expressed in empirical studies, that factor that much influence the value of human capital is reflected in a country that is GDP. In the economic conditions of a country that is constantly changing in terms of human capital, depends on economic, political, social and environmental conditions, but in studies $\left[\begin{array}{lll}1 & \& & 2\end{array}\right]$ there is a significant result to explore human capital by using macro variables.

For the development of the proposed research design model, [3 \& 4] performs the orientation and visualization process of the human capital model for the business activity of the organization, which is described in the form of a measurable and tangible taxonomy using a highly integrated and complex enterprise environment modeling. Some assessments that are very comprehensive, will be allocated and referenced in human capital model, so that the targeted intellectual model is achieved then the need for intellectual capital availability that can make the management of the company materialized. The design model of a process-oriented methodology will result in the proposed modeling for human capital in an identified corporate organization. Several activities and programs that are sustainable make the business process can be useful and growing in accordance with the potential that is owned by intellectual capital.

Another intellectual capital study, specializing in the banking industry, in [5.6 \& 7] explains how the process of merging occurs between the two banks, by looking at the impact of Intellectual Capital analysis on two banks. Their research uses case study techniques with quantitative and qualitative data analysis models. With the first technique of analysis by using descriptive approach formal and informal interview process in carried out with the help of questionnaire. Interviews were conducted on two hundred and twenty-five managers in the company, from the positions of directors, managers, and general managers across branches at both banks. There is one advantage of this research is done, namely the process of direct observation research and analysis by using corporate documents is also done. From the research, we get some important notes which are assumed that there are indicators on the element of intellectual capital maker. Human capital development in both banking industry in doing research is relational and need to do development step to get better knowledge and skill as well as intellectual capital can be made supporter in the improvement of brand, image and encourage improvement of financial performance result in more good.

Further studies conducted by [8,9] give consideration to how exactly capital intellectuals can play a role for the company as a whole in the short-term and long-term context and use the advantages of intellectual capital to improve overall performance. In the paper they present, there is a correlation relationship between human capital development within the company with the level of corporate sustainability in the short term and long term as a whole. Given this it allows the owners of capital to continue to increase intellectual capital, especially related to sustainable corporate problematics. The analytical model used by the writer [8,9] in feeling can be used for the success of the company and for sustainable enterprise development, and by itself will be able to increase the national income. The authors themselves assume that if the concept of the results they can be 
made the basis for research into a better direction related to intellectual capital and economic improvement.

\section{Research Methodology}

This study uses several intellectual capital variables including Value-Added Intellectual Capital Coefficient (VAIC_CM_), Value-Added Capital (_VA_CA_), Human Capital (_VA_HU_), Structural Capital (_ST_VA_), and macroeconomic variables such as Bank Indonesia interest rate (BI_RATE ), Consumer Price Index (CPI), Producer Price Index (IND_PROD_INDEX), Exchange Rate Index (INDEKS_KURS), Indonesian State Inflation (INF). To see the relationship between the variables in the author using the regression proposal model as below:

$$
\begin{aligned}
& { }_{-} \mathrm{ST}_{-} \mathrm{VA}{ }_{-}=\mathrm{a}+{ }_{-} \mathrm{VA} \_\mathrm{CA}{ }_{-}+{ }_{-} \mathrm{VA} \_\mathrm{HU} U_{-}+{ }_{-} \mathrm{VAIC} \_\mathrm{CM}+\mathrm{BI}_{-} \mathrm{RATE}+\mathrm{IHK}+ \\
& \text { IND_PROD_INDEX + INDEKS_KURS + INF (Model 1) }
\end{aligned}
$$

$\mathrm{D}($ ST _VA_ $)=\mathrm{a}+\mathrm{D}($ _VA_CA_ $)+\mathrm{D}($ _VA_HU_ $)+\mathrm{D}($ _VAIC_CM_ $)+\mathrm{D}\left(\mathrm{BI} \_\mathrm{RATE}\right)+\mathrm{D}(\mathrm{IHK})$

$+\mathrm{D}\left(\mathrm{IND} \_\mathrm{PROD}\right.$ INDEX $)+\mathrm{D}\left(\mathrm{INDEKS} \_\mathrm{KURS}\right)+\mathrm{D}(\mathrm{INF}) \quad$ (Model 2)

$$
\begin{aligned}
& \log (\text { STT_VA_ })=\mathrm{a}+\log (\text { VA_CA_ })+\log (\text { VA_HU_ })+\log (\text { VAIC_CM_ })+\log (\text { BI_RATE })+ \\
& \log (\mathrm{IHK})+\log (\mathrm{IND} \text { _PROD_INDEX })+\log (\mathrm{INDEKS} \text { _KURS })+\log (\mathrm{INF})
\end{aligned}
$$

After the model of regression proposals in the can, the authors do a model analysis using multiple regression analysis assisted statistical software. This study uses more than corporate financial statements of 61 companies and macroeconomic data during the period of research data. This research is done to complete by the author during March-April 2018.

\section{Result and Discussion Research}

For microeconomics there is the term human capital that provides a definition of knowledge that refers to the skills, education and training they can. According to [10] originally the term human capital occurred in early 1964, where a Nobel Laureate named Gary S. Becker of the University of Chicago, published the book Human Capital. According to the author, human capital is a term that is used if there is an increase in return on investment in education and on the value of education obtained. In macroeconomics there are several dimensions of education and capital investment that are done to humans. The author considers that there is a contribution of intellectual capital to the development and economic growth of a State. Intellectual capital according to macroeconomic theory, is one of the four economic development factors of a State in addition to the development of natural resources, and technology. Thus, this study assesses the intellectual capital from the side of its influence on the economy by using macroeconomic variables as a means of influence. These results are presented with a form of proposed model for intellectual capital in the author's suggestion in tables 1,2 and 3. 
Table 1: Result for regression analysis with macroeconomic variable

\begin{tabular}{|c|c|c|c|c|c|}
\hline \multicolumn{6}{|c|}{ Dependent Variable:_ST_VA } \\
\hline Variable & Coefficien & Std. Errol & \begin{tabular}{|l|l|} 
t-Statistic & Prob. \\
\end{tabular} & R-squared & 1.000000 \\
\hline $\mathrm{C}$ & 5.310011 & 2.450012 & \begin{tabular}{|l|l|}
21.65202 & 0.0000 \\
\end{tabular} & Adjusted R-squared & 1.000000 \\
\hline VA_CA & -1.000000 & 8.840015 & -1.1300140 .0000 & S.E. of regression & 2.190013 \\
\hline _VA_HU & -1.000000 & 9.710015 & -1.0300140 .0000 & F-statistic & 3.420027 \\
\hline _VAIC_CM & 1.000000 & 6.190015 & 1.6200140 .0000 & Prob(F-statistic) & 0.000000 \\
\hline BI_RATE & -2.110012 & 1.040013 & -20.294090 .0000 & Mean dependent val & r0.424895 \\
\hline IHK & 2.030012 & 1.000013 & 20.325040 .0000 & S.D. dependent var & 1.636415 \\
\hline IND_PROD_INDEX & -2.620013 & 1.210014 & -21.527480 .0000 & Sum squared resid & 2.300023 \\
\hline INDEKS_KÜRS & -2.200013 & 1.020014 & -21.507900 .0000 & Durbin-Watson stat & 2.418652 \\
\hline INF & 1.190013 & 9.380015 & 12.654440 .0000 & & \\
\hline
\end{tabular}

Source: Author proceed

Table 2: Result for regression analysis with macro economic variable with Difference model

\begin{tabular}{|c|c|c|c|c|}
\hline \multicolumn{5}{|c|}{ Dependent Variable: D(_ST_VA_) } \\
\hline Variable & Coefficient & Std. Errort-Statistic Prob. & R-squared & 1.000000 \\
\hline $\mathrm{C}$ & -4.770017 & \begin{tabular}{l|l|l|}
1.950016 & -0.245032 & 0.8065 \\
\end{tabular} & Adjusted R-squared & 1.000000 \\
\hline D(_VA_CA_) & -1.000000 & \begin{tabular}{|l|l|l|}
1.980016 & -5.050015 & 0.0000 \\
\end{tabular} & S.E. of regression & 4.300015 \\
\hline $\mathrm{D}($ (VA_HU_) & -1.000000 & $2.160016-4.6200150 .0000$ & F-statistic & 1.510031 \\
\hline D(_VAIC_CM_) & 1.000000 & \begin{tabular}{l|l|l|}
9.480017 & 1.050016 & 0.0000 \\
\end{tabular} & Prob(F-statistic) & 0.000000 \\
\hline D(BI_RATE) & 1.130014 & \begin{tabular}{|l|l|l|}
1.400015 & 8.061352 & 0.0000 \\
\end{tabular} & Mean dependent var & 1695 \\
\hline $\mathrm{D}(\mathrm{IHK})$ & -1.110014 & \begin{tabular}{|l|l|}
1.430015 & -7.7526890 .0000 \\
\end{tabular} & S.D. dependent var & 208 \\
\hline D(IND_PROD & 1.460015 & \begin{tabular}{|l|l|l|}
1.740016 & 8.377403 & 0.0000 \\
\end{tabular} & Sum s & 027 \\
\hline D(INDEKS_KURS) & 1.240015 & \begin{tabular}{|l|l|l|l|}
1.430016 & 8.654488 & 0.0000 \\
\end{tabular} & Durbin-Watson stat & 2.840263 \\
\hline $\mathrm{D}(\mathrm{INF})$ & -2.710016 & \begin{tabular}{l|l|l|}
1.440016 & -1.880189 & 0.0607 \\
\end{tabular} & & \\
\hline
\end{tabular}

Source: Author proceed

Table 3: Result for regression analysis with macro economic variable with log linier model

\begin{tabular}{|c|c|c|c|c|c|}
\hline \multicolumn{6}{|c|}{ Dependent Variable: LOG(_ST_VA_) } \\
\hline Variable & Coefficient & Std. Errol & t-Statistic Prob. & R-squared & 0.395126 \\
\hline C & 8.763544 & 20.83617 & $0.420593 \mid 0.6742$ & Adjusted R-squared & 0.384652 \\
\hline LOG(_VA_CA_) & -0.203888 & 0.028656 & -7.1151320 .0000 & S.E. of regression & 0.440209 \\
\hline LOG(_VA_HU_) & -0.200656 & 0.073029 & -2.7476060 .0062 & Sum s & 89.52823 \\
\hline LOG(_VAIC_CM_) & 0.991677 & 0.086894 & 11.412520 .0000 & Log likelihood & -277.3184 \\
\hline LOG(BI_RATE) & -1.536468 & 1.440123 & -1.0669010 .2866 & stic & 37.72447 \\
\hline LOG(IHK) & 0.069216 & 0.865488 & 0.0799730 .9363 & Prob(F-statistic) & 0.000000 \\
\hline LOG(IND_PROD_. & -0.4 & 2.669963 & \begin{tabular}{|l|l|}
-0.178702 & 0.8583 \\
\end{tabular} & Mean dependent $\mathrm{v}$ & $\mathrm{r}-0.705922$ \\
\hline LOG(INDEKS_KURS) & -1.344078 & 1.642310 & -0.8184070 .4135 & S.D. dependent var & 0.561175 \\
\hline LOG(INF) & 0.156208 & 0.137333 & \begin{tabular}{|l|l|}
1.137439 & 0.2559 \\
\end{tabular} & Durbin-Watson stat & 0.567684 \\
\hline
\end{tabular}

Source: Author proceed

The results presented in Table 1, 2 and 3 above, provide evidence that there is a significant relationship between intellectual capital variable and macroeconomic variables with the proposed regression models 1 and 2, for 3 only the intellectual variable related significantly. The results of this test support the explanation put forward by [10], where with the existence of intellectual capital indirectly there are economic actions that are influenced. This explanation is reinforced by the theory described in book [11], where the occurrence of competitiveness in the world economy demands an increase in the quality of human resources that ultimately improve the sustainable 
economy. The occurrence of intellectual development of capital which is accompanied by the development will be able to shift the aggregate production function in the economy of a State upwards, in due to the progress in productivity because of the increase in human capital value. It should be noted that there is an international difference in the intellectual capital standard will result in a difference in income [12].

\section{Conclusion}

From the study, it can be seen that there are several reasons why intellectual capital that is qualified and increased can create innovation and increase productivity, so that the economic increase from the income side also increases. In table 1 and 2 it is clear that significant partial and simultaneous relationship between several intellectual capital variables and some macroeconomic variables are interconnected, but with the proposed regression model 3 this state becomes not the same, only intellectual capital variable are interrelated significant partially variable macroeconomics is not. But simultaneously for 3 models of research proposals have a significant or interrelated impact. Data and results are displayed in this study describes the intellectual capital must be able to grow continuously, so that the intelligence of growth and development of a nation can be achieved.

\section{References}

[1] Noorbakhsh, F., et. all. (2001). Human capital and FDI inflows to developing countries: New empirical evidence. World Development, 29(9), 1593-1610.

[2] Liepe, Z and Sakalas, A. (2013). DETERMINATION OF HUMAN CAPITAL VALUE AT MACRO LEVEL, ECONOMICS AND MANAGEMENT: 18 (2), http://dx.doi.org/10.5755/j01.em.18.2.4101.

[3] Galeitzke, M. et all. (2016), Process-oriented design methodology for the (inter-) organizational intellectual capital management, Procedia CIRP 40, 674 - 679, doi: 10.1016/j.procir.2016.01.153.

[4] Pablos, P., A, (2004), guideline for building an intellectual capital statement: the 3R model, Int. J. Learn. Intellect. Cap. 1.

[5] Jordão, R, V, D et all, (2017), Intellectual capital in mergers and acquisitions: a case study in a world-class financial institution, Re vista de Administração 52, 268 - 284, http://dx.doi.org/10.1016/j.rausp.2017.05.007.

[6] Jardon, C. M., and Martos, M. S. (2012). Intellectual capital as competitive advantage in emerging clusters in Latin America. Journal of Intellectual Capital,13(4), 462-481.

[7] Joia, L. A. (2000). Measuring intangible corporate assets: Linking business strategy with intellectual capital. Journal of Intellectual Capital, 1(1), 68-84.

[8] Makarov, P, (2010), Intellectual Capital as an Indicator of a Sustainable Development, Journal of Sustainable Development, Vol. 3, No. 3, www.ccsenet.org/jsd.

[9] Ståhle, P. (2008). National Intellectual Capital as an Economic Driver: Perspectives on Identification and Measurement, download in http://www.stahle.fi/National_Intellectual_Capital_as_an_Economic_Driver_200408_final.pdf

[10] Becker, G. (1993): "Human capital, A theoretical and empirical analysis", 3rd edition, Chicago, published University of Chicago Press.

[11] Samuelson, A.P. and William, N, D. (1995): "Economics", Columbus OHIO, MGraw- Hill Publishing.

[12] Mankiw, N.G. (1994): "Macroeconomics", Richmond, Worth.

[13] https://www.tutor2u.net/economics/blog/unit-4-macro-human-capital-and-economic-growth

[14] http://faculty.chicagobooth.edu/ruey.tsay/teaching/introTS/

[15] http://wenders.people.ua.edu/applied-econometric-time-series.html 
[16] http://econ.lse.ac.uk/courses/ec220/G/ieppt/series2/

*Corresponding author.

E-mail address: bagyo1972@gmail.com/zulaikhaw@hotmail.com/desmadi.saharuddin@uinjkt.ac.id 